\title{
RESPONSE OF WHEAT (TRITICUM AESTIVUM L.) PLANTS TO FOLIAR SPRAYING OF SOME BIO-STIMULANTS (YEAST EXTRACT, ARGININE, B12 AND THEIR INTERACTIONS)
}

\author{
Mohamed A. Ismail and Mohamed A. Amin
}

Botany and Microbiology Department, Faculty of Science, Al-Azhar University, Cairo, Egypt.

\begin{abstract}
A field experiments were carried out in season of 2013/2014 at Botanical garden, Botany and Microbiology Dept., Fac. of Sci., Al-Azhar Univ., Nasr City, Cairo, to study the effect of foliar applications of some bio-stimulants (dry yeast extracts, arginine, B12 and their interactions) on growth, total yield, quality and some chemical constituents of wheat plants. Results showed that, foliar spraying of wheat plants with bio-stimulants especially yeast extract had a significant effect on vegetative growth, yield and quality. Shoot fresh weight of wheat plants were improved by yeast extract at all doses and B 12 foliar application during the first stage. Results showed that addition of any of these treatments has been significantly increased the dry weight of roots during two stages as compared to the control in almost cases. The contents of pigments of wheat plants showed, significant increases in chlorophyll $a, b, a+b$ and carotenoids content in response to various treatments. Results indicated that foliar application of all these treatments increased amylase activity compared to control during the second stage. Application of yeast $\left(6 \mathrm{gl}^{-1}\right)+B_{12}$ or yeast $\left(6 \mathrm{gl}^{-1}\right)+$ arginine showed the heaviest 100 seeds weight $(4.16$ and $4.11 \mathrm{~g})$ respectively as a compared with untreated plant $(2.9 \mathrm{~g})$. Moreover it could be concluded that foliar spraying of yeast $(4 \mathrm{~g} / \mathrm{l})+$ Arg. led to obtain the highest values of yielded seeds protein, while the highest values of yielded carbohydrates at yeast $(4 \mathrm{~g} / \mathrm{l})+B_{12}$ of wheat plants.
\end{abstract}

\section{INTRODUCTION}

Wheat (Triticum aestivum L.), is the most important world's leading cereal crop. In Egypt wheat is considered the main crop used as source for human food. Although wheat production per unit area in Egypt has significantly increased during the past years, wheat production supplies about $40 \%$ of its annual domestic demand only (FAO, 2008).

The ccurrent global scenario firmly emphasizes the need to adopt eco-friendly agricultural practices for sustainable agriculture (Fawzy et al., 2012). Organic farming is 'zero impact' on the environment www.seedbuzz.com. Biofertilizers are low cost, effective and renewable source of plant nutrients to supplement chemical fertilizers, In addition to their role in enhancing the growth of the plants, biofertilizers can act as biocontrol agents in the rhizosphere at the same time. This synergistic effect, when present, increases the role of application of bio-fertilizers in the sustainable agriculture. Many attempts were made to prepare a bio-fertilizer from wastes using effective microorganism including bacteria and yeasts. Yeasts synthesize antimicrobial and other useful substances required for plant growth from amino acids and sugars secreted by bacteria, organic matter and plant roots (Boraste et al., 2009). Agamy et al., (2013) showed that, the use of yeast as a bio-fertilizer in agriculture has received considerable attention because of their bioactivity and safety for human and the environment. Organic farming strategy is growing rapidly all over the world to conserve human health and the environment, which became under risk because of the unbalance use of pesticides and chemical fertilizers. The dangerous effect is because the repeated use of chemical fertilizers destroys soil biota (Boraste et al., 2009). Saccharomyces cerevisiae is considered as a new promising plant growth promoting yeast for different crops. Recently, it became a positive alternative to chemical fertilizers safely used for human, animal and environment (Omran, 2000). It is known that yeast is considered as a natural source of cytokinins that stimulate cell division and enlargement as well as the synthesis of proteins, nucleic acids and chlorophyll (Fathy and Farid, 1996). Foliar application of yeast extract and ascorbic acid increased vegetative growth of eggplant (El-Tohamy et al., 2008). Also, Abou El-yazied and Mady (2012) found that yeast extract stimulated growth of broad bean and increased amino acid, auxins and cytokinins 75 days after sowing of broad bean.

Growth regulators and vitamins are known to 
affect plant growth through primary and secondary metabolism (Ewais et al. 2003 and Reda et al.2007). Rafique, et al. (2011) showed the best results on seedling growth, fresh and dry matter production of pumpkin seedlings due to $30 \mathrm{mg}$ $\mathrm{L}^{-1}$ ascorbic acid treatments.

Arginine is one of the essential amino acids (considered the main precursor of polyamines which produced by decarboxylation of arginine via arginine decarboxylase to form putrescine (Bocherueu, 1999). Amino acids are well known as bio-stimulants, which have positive effects on plant growth, yield and significantly mitigate the injuries caused by abiotic stresses (Kowalczyk and Zielony, 2008). Polyamines and their precursor arginine have been implicated as vital modulators in a variety of growth, physiological and developmental processes in higher plants (Glastone and Kaur-sahney, 1990). Fawzy et al., 2012) showed that, foliar spraying of Chinese garlic plants with bio-stimulants especially amino acids compound had a significant effect on vegetative growth, yield and quality. The application of arginine significantly promoted the growth and increased the fresh and dry weights in bean (Nassar et al., 2003); in wheat Abd ElMonem, 2007) and El-Bassiouny et al., 2008). Therefore, the purpose of this study is an attempt for investigating the effect of yeast extract, arginine, B12 and their interaction on growth, yield and some biochemical constituents of wheat plant in order to select a suitable bio stimulant to the applied fairly to enhance growth and yield quality.

\section{MATERIALS AND METHODS}

Seeds of wheat "Triticum aestivum L.)" (Var. suds 1) was obtained from Agricultural Research Centre, Ministry of Agriculture, Giza, Egypt. Uniform wheat seeds were planted in natural loamy soil conditions in a plot (12 $\mathrm{m}$ width and $15 \mathrm{~m}$. length) containing 12 groups representing the following treatments: yeast at 29 /liter, $4 \mathrm{~g} /$ liter and $6 \mathrm{~g} /$ liter were applied to the $2^{\text {nd }}, 3^{\text {rd }}$ and $4^{\text {th }}$ groups, respectively; Arginine at 200 ppm was applied to the $5^{\text {th }}$ groups. The $6^{\text {th }}$ group was treated with $B_{12}$ at $200 \mathrm{ppm}$. The $7^{\text {th }}$ and $8^{\text {th }}$ groups were treated with (yeast at $2 \mathrm{~g} /$ liter+ Arg at $200 \mathrm{ppm}$ ) and (yeast at $2 \mathrm{~g} /$ liter+ $\mathrm{B}_{12}$ at 200 $\mathrm{ppm}$ ) respectively. yeast at $4 \mathrm{~g} / \mathrm{liter}+\mathrm{Arg}$ at 200 ppm and yeast at $4 \mathrm{~g} / \mathrm{liter}+\mathrm{B}_{12}$ at $200 \mathrm{ppm}$, respectively were applied to the $9^{\text {th }}$ and $10^{\text {th }}$. The $11^{\text {th }}$ and $12^{\text {th }}$ groups were treated with yeast at 6 $\mathrm{g} /$ liter+ Arg at $200 \mathrm{ppm}$ and yeast at $6 \mathrm{~g} / \mathrm{liter}+$ $\mathrm{B}_{12}$ at $200 \mathrm{ppm}$, respectively. The first group was left aside untreated serving as control. The seeds were sown on one side of the ridge, with $10 \mathrm{~cm}$ apart between the hills. In the Botanical garden, Botany and Microbiology Dept., Fac. of Sci., Al- Azhar Univ., Nasr City, Cairo, Egypt, developed plants were irrigated whenever required. Concentrations of the used yeast extract, arginine and vitamin $\mathrm{B}_{12}$ were chosen according to a preliminary experiment in which they caused a maximum germination percentage. The plants were sprayed twice with the above mentioned treatments, the first and second were added at 33 and 70 days of plant age respectively. The plant samples were collected for analysis when the plants were 40 (Stage I) and 77 (Stage II) days old. At the end of the growth season, analysis of the seeds yielded from the different treatments and the control were done. Chlorophylls contents were estimated using the method of Vernon and Selly (1966). Carotenoids contents of were estimated according to Lichtentahler (1981). Soluble carbohydrates were measured according to the method of Umbriet et al. (1969). Contents of soluble proteins were estimated according to the methods of lowery et al. (1951). A phenolic compound (mg/100 g of dry wt) was carried out according to that method described by Daniel et al. (1972). Activities of amylases were determined using the method of Afifi et al. (1986). Statistical analysis of the obtained results was done using (L.S.D.) according to Snedecor and Cochran (1982).

\section{RESULTS AND DISCUSSION}

\section{Growth parameters}

Our results in table (1) showed that, shoot length of wheat plants were significantly enhanced as a result of application of yeast $(2 \mathrm{~g} / \mathrm{l})$, yeast $(2 \mathrm{~g} / \mathrm{l})+\mathrm{B}_{12}$ and yeast $(6 \mathrm{~g} / \mathrm{l})+$ arginine foliar application for the first growth stage. On the other hand, foliar application had no significant effect on root growth and number of leaves parameter during all stages and shoot length during 
Response of wheat (Triticum aestivum L.) plants to Foliar Spraying of Some Bio stimulants 3 the second stages. Data in Table (2) indicated that the overall fresh weights of shoot of wheat plants were improved by yeast extract at all doses and $\mathrm{B}_{12}$ foliar application during the first stage. Results showed that addition of any of this treatments has been significantly increased the dry weight of roots during two stages as compared to the control in almost cases. Increase in fresh and dry weight of the root is a good indicator for enhancement of the yield. A growing number of studies indicate that plant root growth may be directly or indirectly enhanced by yeasts in the rhizosphere (Nassar et al., 2005; El-Tarabily and Sivasithamparam, 2006; Cloete et al., 2009). Increase in vegetative growth of plants because of the application of bio-fertilizers was reported in previous works (Mahdi et al., 2010). In agreement with our results, Wali Asal (2010) indicated that yeast has good efficiency on growth characters of wheat plants. Nakayan et al., (2009) reported that combination of yeast strain Pichia sp. CC1 and a half dose of chemical fertilizer $(1 / 2 \mathrm{CF})$ increased lettuce dry weight to $107 \%$. In addition, yeast content of macro and micronutrients, growth regulators and vitamins stimulate the plant to build up dry matters (Hesham and Mohamed, 2011). The promoting effect of yeasts could be due to the biologically active substance produced by these biofertilizers such as auxins, gibberellins, cytokinins, amino acids and vitamins (Bahr and Gomaa, 2002). Fawzy et al., (2012) found that, foliar sprayed of amino acid significantly influenced dry weight of leaves, neck and bulb of Chinese garlic plants.

\section{2- Photosynthetic Pigments:}

The contents of chlorophyll a; $b$; total chlorophyll $(a+b)$ and carotenoids of wheat plants (Table 3) showed, significant increases in chlorophyll $\mathrm{a}, \mathrm{b}, \mathrm{a}+\mathrm{b}$ and carotenoids content in response to various treatments applied yeast extracts, arginine, $\mathrm{B}_{12}$ and their interactions. The obtained results agree with those observed by a number of investigators for example, Agamy et al., (2013) showed that application of the yeasts (Kluyveromyces walti, Pachytrichospora transvaalensis and Sacharromycopsis cataegensis) significantly increased the photosynthetic pigments of sugar beet. Also, showed that, the application yeasts induced the formation of photosynthetic pigments (chlorophyll $a$ and $b$ ). The positive effect of yeasts on chl. $a$ and $b$ is in consistence with the result obtained by Hayat (2007) and Stino et al. (2009), who stated that the increase in chl. $a$ and $b$ leads to a consequent increase in total carbohydrates, because the yeast application could enhance role in cell division, cell elongation producing more leaf area. Hussain et al. (2002) reported that Saccharomyces sp. is among the microorganisms, which improve crop growth and yield by increasing photosynthesis, producing bioactive substances, such as hormones and enzymes and controlling soil diseases. Castelfranco and Beale (1983) stated that the increase in photosynthetic pigment formation could be attributed to the role of yeast cytokinins delaying the aging of leaves by reducing the degradation of chlorophyll and enhancing the protein and RNA synthesis. The application of arginine significantly promoted the growth and increased chlorophylls $\mathrm{a}$ and $\mathrm{b}$ and carotenoids in bean (Nassar et al., 2003); in wheat Abd El-Monem, 2007) and El-Bassiouny et al., 2008).

\section{3- Soluble Carbohydrates and proteins:}

In the present study, it was found (Table 4) that carbohydrates contents in shoots of wheat plants, were significantly increased in response to Arginine, Yeast (2 g/l)+Arg., Yeast (4 g/l) +Arg. and Yeast $(6 \mathrm{~g} / \mathrm{l})+$ Arg. during the two seasons. While protein contents in shoots of wheat plants, were significantly increased in response to Yeast $(2 \mathrm{~g} / \mathrm{l}), \mathrm{B} 12$ and yeast $(2 \mathrm{~g} / \mathrm{l})+$ Arg. Data in Table (4) also, noted that the activities of amylases enzymes was positively affected by the foliar spray of all treatments during the second stages.

Amino acids are the fundamental ingredients for the process of protein synthesis. The importance of nitrogen or amino acids came from their widely use for the biosynthesis of large variety of non-protein nitrogenous materials i.e., pigments, vitamins, coenzymes, purine and pyrimidine bases (Kamar and Omar, 1987).

The obtained results are in harmony with those reported by Agamy et al., (2013) showed that application of the yeasts significantly $(\mathrm{P}<$ 0.05 ) increased the soluble sugars, sucrose, and total soluble proteins of sugar beet. Abdel-Halim 
molecular weights (MWs) ranged from about 9.97 to $147.47 \mathrm{KDa}$ in the yielded wheat seeds in response to treatment with different concentrations of yeast extract, Arg., B12 and their interactions. Results of the present study revealed that the electrophoregram of the plants treated with different concentrations of yeast extract, arginine, B12 and their interactions exhibited the appearance of different protein bands of others presented in the control samples. The obtained results showed the presence of 7 monomorphic common polypeptide bands, 11 polymorphic common polypeptide bands. The obtained results are in agreement with those reported by Fawzy., (2012) clearly showed that, foliar spray- ing of amino acid significantly increased protein content in tissue of Chinese garlic bulb. Ekmekçi and Karaman (2012) showed that application of $100 \mathrm{ppm}$ ascorbic acid (vitamin C) increased the intensity of protein bands as well as synthesized additional new proteins of Silybum marianum (L.) plants.

\section{Conclusion}

Our results are promising in the field of biofertilizers. Foliar application of yeast $(2,4$ and $6 \mathrm{~g}$ $1^{-1}$ ), amino acids (arginine) and vitamin $\left(\mathrm{B}_{12}\right)$ as bio-stimulants can be recommended to enhance total yield and yield quality of wheat, while foliar application of yeast was the best for vegeta-

Table (1): Effect of yeast extract (g/l), arginine (ppm), B12 (ppm) and their interactions on shoot length, root length and number of leaves of Triticum aestivum L. (var. suds 1) plants. Values given are means of ten replicates.

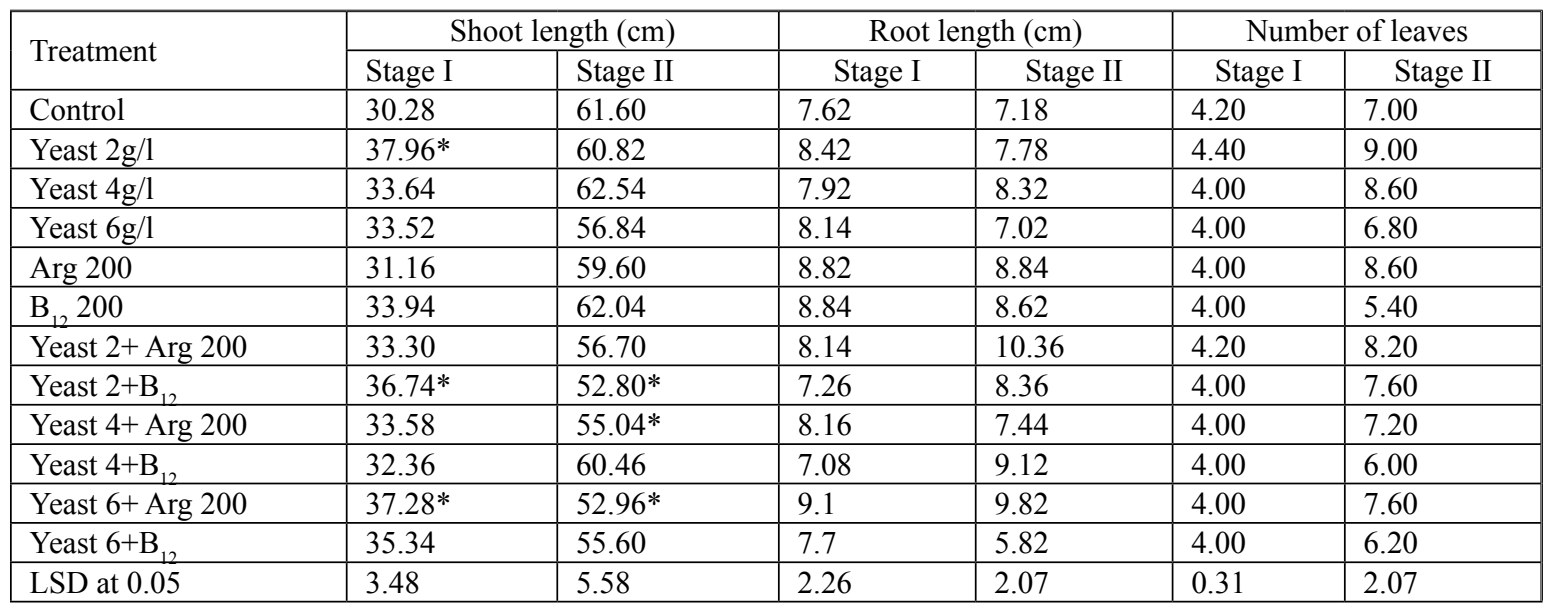

* Significant at $5 \%$ confidence level.

Table (2): Effect of yeast extract (g/l), arginine (ppm), B12 (ppm) and their interactions on fresh and dry weight of shoots and roots of Triticum aestivum $\mathrm{L}$. (var. suds 1) plants. Values given are means of ten replicates.

\begin{tabular}{|c|c|c|c|c|c|c|c|c|}
\hline \multirow{2}{*}{ Treatment } & \multicolumn{2}{|c|}{ F. wt. of shoots (g.) } & \multicolumn{2}{|c|}{ D. wt. of shoots (g.) } & \multicolumn{2}{|c|}{ F. wt. of roots (g.) } & \multicolumn{2}{|c|}{ D. wt. of roots (g.) } \\
\cline { 2 - 10 } & Stage I & Stage II & Stage I & Stage II & Stage I & Stage II & Stage I & Stage II \\
\hline Control & 0.63 & 3.72 & 0.09 & 0.93 & 0.10 & 0.22 & 0.015 & 0.031 \\
\hline Yeast 2g/1 & $1.08^{*}$ & 4.14 & 0.14 & 1.15 & $0.32^{*}$ & $0.40^{*}$ & $0.046^{*}$ & $0.057^{*}$ \\
\hline Yeast 4g/1 & $0.99^{*}$ & $5.48^{*}$ & 0.14 & $1.31^{*}$ & 0.14 & 0.39 & $0.020^{*}$ & $0.056^{*}$ \\
\hline Yeast 6g/1 & $0.97^{*}$ & 3.15 & $0.15^{*}$ & 0.89 & 0.20 & 0.30 & $0.029^{*}$ & $0.043^{*}$ \\
\hline Arg 200 & 0.81 & 3.43 & 0.11 & 0.92 & 0.14 & 0.32 & $0.020^{*}$ & $0.046^{*}$ \\
\hline B12 200 & $1.16^{*}$ & 3.25 & $0.16^{*}$ & 1.01 & 0.22 & 0.28 & $0.032^{*}$ & $0.040^{*}$ \\
\hline Yeast 2+ Arg 200 & 0.92 & 3.25 & 0.13 & 0.81 & 0.16 & $0.41^{*}$ & $0.023^{*}$ & $0.059^{*}$ \\
\hline Yeast 2+B12 & $0.98^{*}$ & 3.29 & 0.13 & 0.86 & 0.11 & 0.23 & $0.016^{*}$ & $0.033^{*}$ \\
\hline Yeast 4+ Arg 200 & 0.89 & 3.03 & 0.12 & 0.91 & 0.11 & 0.18 & $0.016^{*}$ & $0 . .026^{*}$ \\
\hline Yeast 4+B12 & 0.93 & 3.64 & 0.14 & 1.13 & $0.32^{*}$ & 0.06 & $0.045^{*}$ & $0.009^{*}$ \\
\hline Yeast 6+ Arg 200 & $0.99^{*}$ & 3.17 & 0.14 & 0.79 & 0.17 & 0.21 & $0.025^{*}$ & $0.030^{*}$ \\
\hline Yeast 6+B12 & $1.12^{*}$ & $2.49^{*}$ & $0.26^{*}$ & 0.78 & 0.18 & 0.25 & $0.025^{*}$ & $0 . .035^{*}$ \\
\hline LSD at 0.05 & 0.31 & 1.19 & 0.057 & 0.35 & 0.19 & 0.18 & 0.0004 & 0.0003 \\
\hline
\end{tabular}

* Significant at $5 \%$ confidence level. 
Response of wheat (Triticum aestivum L.) plants to Foliar Spraying of Some Bio stimulants 5 Table (3): Effect of yeast extract (g/l), arginine (ppm), B12 (ppm) and their interactions on chlorophyll and carotenoids contents (mg/g. F. wt) of Triticum aestivum L. (var. suds 1) plants. Values given are means of three replicates

\begin{tabular}{|c|c|c|c|c|c|c|c|c|}
\hline \multirow{2}{*}{ Treatment } & \multicolumn{2}{|c|}{ Chlorophyll a } & \multicolumn{2}{c|}{ Chlorophyll b } & \multicolumn{2}{c|}{ Chlorophyll a+b } & \multicolumn{2}{c|}{ Carotenoids } \\
\cline { 2 - 9 } & Stage I & Stage II & Stage I & Stage II & Stage I & Stage II & Stage I & Stage II \\
\hline Control & 9.66 & 11.83 & 2.605 & 7.05 & 12.26 & 18.88 & 3.405 & 5.35 \\
\hline Yeast 2g/1 & $12.43^{*}$ & $17.76^{*}$ & $2.933^{*}$ & $12.48^{*}$ & $15.36^{*}$ & $30.24^{*}$ & $4.303^{*}$ & $7.99^{*}$ \\
\hline Yeast 4g/l & $8.51^{*}$ & $29.53^{*}$ & $1.805^{*}$ & $19.05^{*}$ & $10.31^{*}$ & $48.59^{*}$ & $3.317^{*}$ & 6.13 \\
\hline Yeast 6g/l & $8.66^{*}$ & $23.18^{*}$ & $2.122^{*}$ & $11.80^{*}$ & $10.78^{*}$ & $34.99^{*}$ & $2.72^{*}$ & 5.86 \\
\hline Arg 200 & $9.25^{*}$ & $19.94^{*}$ & $2.082^{*}$ & $9.80^{*}$ & $11.33^{*}$ & $29.74^{*}$ & $3.43^{*}$ & 6.17 \\
\hline B12 200 & $10.04^{*}$ & $19.58^{*}$ & $2.257^{*}$ & $10.46^{*}$ & $12.30^{*}$ & $30.04^{*}$ & $3.56^{*}$ & 5.49 \\
\hline Yeast 2+Arg & $9.99^{*}$ & $21.62^{*}$ & $2.134^{*}$ & $11.40^{*}$ & $12.12^{*}$ & $33.03^{*}$ & $3.59^{*}$ & 5.32 \\
\hline Yeast 2+B12 & $7.86^{*}$ & $44.26^{*}$ & $4.629^{*}$ & $23.17^{*}$ & $12.49^{*}$ & $67.43^{*}$ & $1.00^{*}$ & $11.72^{*}$ \\
\hline Yeast 4+Arg & $8.51^{*}$ & $36.05^{*}$ & $1.776^{*}$ & $19.34^{*}$ & $10.29^{*}$ & $55.39^{*}$ & $3.16^{*}$ & $10.99^{*}$ \\
\hline Yeast 4+B12 & $8.23^{*}$ & $27.92^{*}$ & $2.195^{*}$ & $17.84^{*}$ & $10.42^{*}$ & $45.75^{*}$ & $2.99^{*}$ & 6.99 \\
\hline Yeast 6+Arg & $5.62^{*}$ & $33.33^{*}$ & $1.431^{*}$ & $16.86^{*}$ & $7.05^{*}$ & $50.20^{*}$ & $2.24^{*}$ & $9.14^{*}$ \\
\hline Yeast 6+B12 & $7.46^{*}$ & $19.62^{*}$ & $1.403^{*}$ & $10.64^{*}$ & $8.86^{*}$ & $30.26^{*}$ & $2.72^{*}$ & 5.41 \\
\hline LSD at 0.05 & 0.053 & 0.604 & 0.092 & 0.910 & 0.092 & 0.481 & 0.053 & 1.03 \\
\hline
\end{tabular}

* Significant at $5 \%$ confidence level.

Table (4): Effect of yeast extract (g/l), arginine (ppm), B12 (ppm) and their interactions on total soluble carbohydrates, proteins contents and activities of amylases enzymes (mg/g. dry weight) of Triticum aestivum L. (var. suds 1) plants. Values given are means of three replicates.

\begin{tabular}{|c|c|c|c|c|c|c|}
\hline \multirow{2}{*}{ Treatment } & \multicolumn{2}{|c|}{ Shoot carbohydrates } & \multicolumn{2}{c|}{ Shoot proteins } & \multicolumn{2}{c|}{ Amylases } \\
\cline { 2 - 7 } & Stage I & Stage II & Stage I & Stage II & Stage II & Stage I \\
\hline Control & 1.36 & 0.85 & 30.44 & 19.44 & 1.37 & 1.56 \\
\hline Yeast 2g/1 & 0.95 & $1.14^{*}$ & $34.09^{*}$ & $24.40^{*}$ & $1.06^{*}$ & $1.81^{*}$ \\
\hline Yeast 4g/1 & 1.50 & $0.96^{*}$ & $38.24^{*}$ & $14.79^{*}$ & $0.67^{*}$ & $1.85^{*}$ \\
\hline Yeast 6g/1 & 1.84 & $1.08^{*}$ & $33.98^{*}$ & 20.11 & $0.58^{*}$ & $1.82^{*}$ \\
\hline Arg 200 & $2.02^{*}$ & $1.46^{*}$ & $33.84^{*}$ & 19.41 & $0.97^{*}$ & $1.65^{*}$ \\
\hline B12 200 & 1.42 & $2.07^{*}$ & $33.45^{*}$ & $22.56^{*}$ & $0.75^{*}$ & $1.82^{*}$ \\
\hline Yeast 2+Arg & $2.50^{*}$ & $0.94^{*}$ & $34.48^{*}$ & $21.97^{*}$ & $0.41^{*}$ & $1.90^{*}$ \\
\hline Yeast 2+B12 & 2.07 & $0.99^{*}$ & $39.22^{*}$ & $9.24^{*}$ & $0.17^{*}$ & $1.72^{*}$ \\
\hline Yeast 4+Arg & $3.42^{*}$ & $1.09^{*}$ & $38.44^{*}$ & $16.60^{*}$ & $0.86^{*}$ & $1.80^{*}$ \\
\hline Yeast 4+B12 & 1.85 & $1.33^{*}$ & $11.05^{*}$ & $16.01^{*}$ & $0.98^{*}$ & $1.96^{*}$ \\
\hline Yeast 6+Arg & $3.94^{*}$ & $1.09^{*}$ & $11.61^{*}$ & 19.91 & 1.41 & $1.83^{*}$ \\
\hline Yeast 6+B12 & 1.69 & $0.59^{*}$ & $11.11^{*}$ & $16.12^{*}$ & 1.38 & $1.73^{*}$ \\
\hline LSD at 0.05 & 0.608 & 0.053 & 1.26 & 1.005 & 0.12 & 0.053 \\
\hline
\end{tabular}

* Significant at $5 \%$ confidence level.

Table (5): Effect of yeast extract (g/l), arginine (ppm), B12 (ppm) and their interactions of yield components of Triticum aestivum L. (var. suds 1 ). Values given are means of ten replicates.

\begin{tabular}{|c|c|c|c|c|c|}
\hline Treatment & $\begin{array}{c}\text { Length of } \\
\text { spike }\end{array}$ & Weight of spike & wt. seeds $\backslash$ spike & $\begin{array}{c}\text { No. of } \\
\text { seeds/ plant }\end{array}$ & $\begin{array}{c}\text { Wt. of 100 } \\
\text { seeds }(\mathrm{g})\end{array}$ \\
\hline Control & 11.22 & 1.04 & 0.59 & 20.60 & 2.90 \\
\hline Yeast 2g/1 & 11.80 & 1.13 & $0.82^{*}$ & 19.00 & 4.01 \\
\hline Yeast 4g/1 & 11.50 & 1.00 & 0.66 & 21.10 & $3.28^{*}$ \\
\hline Yeast 6g/1 & 11.00 & 1.05 & 0.64 & 22.20 & $3.65^{*}$ \\
\hline Arg 200 & $10.25^{*}$ & $0.58^{*}$ & $0.42^{*}$ & $13.80^{*}$ & $4.03^{*}$ \\
\hline B12 200 & 10.73 & 1.00 & 0.67 & 17.00 & $3.67^{*}$ \\
\hline Yeast 2+Arg & 11.13 & 0.98 & 0.60 & $15.40^{*}$ & $3.15^{*}$ \\
\hline Yeast 2+B12 & $10.04^{*}$ & 0.82 & 0.53 & 17.00 & $3.45^{*}$ \\
\hline Yeast 4+ Arg & $9.35^{*}$ & 0.84 & 0.44 & 17.20 & $3.70^{*}$ \\
\hline Yeast 4+B12 & 10.59 & 1.02 & 0.69 & 18.30 & $3.30^{*}$ \\
\hline Yeast 6+ Arg & $9.69^{*}$ & $0.69^{*}$ & $0.41^{*}$ & $10.00^{*}$ & $4.11^{*}$ \\
\hline Yeast 6+B12 & $8.30^{*}$ & 1.00 & 0.63 & 17.40 & $4.16^{*}$ \\
\hline LSD at 0.05 & 0.88 & 0.23 & 0.16 & 4.97 & 0.092 \\
\hline
\end{tabular}

\footnotetext{
* Significant at $5 \%$ confidence level.
} 
(1995) who observed that ascorbic acid increased protein content of wheat grains. Hussain et al. (2002) reported that Saccharomyces sp. is among the microorganisms, which improve crop growth and yield by increasing photosynthesis, producing bioactive substances, such as hormones and enzymes. The increase in the total soluble proteins content could be attributed to the growth hormones produced by yeast (Khalil and Ismael, 2010), direct stimulation of the synthesis of protein (Stino et al., 2009), providing plants with essential nutrient elements required for protein formation (Hayat, 2007).

\section{4- Vield Responses:}

Results recorded in table (5) indicated that foliar application of yeast extract, arginine and B12 increased significantly the weight of 100 seeds ( $\mathrm{g}$ ) of wheat plants. The highest value was obtained with plants treated with yeast extract at $6 \mathrm{~g} / 1+\mathrm{B} 12$. Yeast extract at $2 \mathrm{~g} / 1$ leads to increase in the weight seeds /plant about 39\% compared with untreated plants. Many studies have been proved that amino acids can directly or indirectly influence the physiological activities in plant growth and development. In addition, reported that the foliar application of amino acids caused an enhancement in fruit yield and its components (Kamar and Omar 1987) on cucumber (El-Shabasi et al., 2005) on garlic (Awad et al., 2007) on potato, (Al-Said and Kamal 2008) on sweet pep- per. The positive effect of yeast is supported by the findings of Mekki and Ahmed (2005). They stated that the increase in yield components because of yeast treatment is mainly attributed to the effect of yeast, which can play a very significant role in making available nutrient elements for plants. Hussain et al. (2002) reported that Saccharomyces sp. is among the microorganisms, which improve crop growth and yield by increasing photosynthesis.

\section{5- Metabolic responses and Protein electropho- retic patterns of yield. .}

Result presented in table (6) showed that the foliar spray of all doses of this treatments increased significantly total seed protein contents, while seed carbohydrate contents only improve in response to yeast $(2 \mathrm{~g} / \mathrm{l})+\mathrm{B} 12$ and yeast $(4 \mathrm{~g} / \mathrm{l})$ $+\mathrm{B} 12$. Seed phenols contents increased significantly at yeast $(6 \mathrm{~g} / \mathrm{l})$, yeast $(4 \mathrm{~g} / \mathrm{l})+\arg$., yeast $(6 \mathrm{~g} / \mathrm{l})+\mathrm{B} 12$ and yeast $(6 \mathrm{~g} / \mathrm{l})+\mathrm{B} 12$. Generally, it could be found that, the highest amount of protein in seeds of wheat was found by foliar application of yeast $(2 \mathrm{~g} / \mathrm{l})+\mathrm{B} 12$. On the contrary, the lowest amount of protein was recorded by control treatment. With regard of phenolic and carbohydrates contents, the highest amount recorded by foliar sprayed of yeast $(4 \mathrm{~g} / \mathrm{l})+\mathrm{B} 12$.

SDS-PAGE in Figure (1) and results in Table (7) revealed the changes in protein patterns with total number of 18 bands with different

Table (6): Effect of yeast extract (g/l), arginine (ppm), B12 (ppm) and their interactions on total soluble carbohydrates, proteins and phenols of the seed yield of Triticum aestivum L. (var. suds 1). Values given are means of three replicates.

\begin{tabular}{|c|c|c|c|}
\hline Treatment & Carbohydrates $(\mathrm{mg} / \mathrm{g})$ & $\begin{array}{c}\text { Proteins } \\
(\mathrm{mg} / \mathrm{g})\end{array}$ & $\begin{array}{c}\text { Total phenols } \\
(\mathrm{mg} / 100 \mathrm{~g})\end{array}$ \\
\hline Control & 11.31 & 30.61 & 10.28 \\
\hline Yeast $2 \mathrm{~g} / \mathrm{l}$ & $8.43^{*}$ & $45.49^{*}$ & 15.78 \\
\hline Yeast 4g/1 & $7.44^{*}$ & $36.18^{*}$ & 15.81 \\
\hline Yeast 6g/l & $9.25^{*}$ & $34.40^{*}$ & $21.53^{*}$ \\
\hline Arg 200 & 11.77 & $39.94^{*}$ & 14.60 \\
\hline B12 200 & $8.43^{*}$ & $40.81^{*}$ & 12.97 \\
\hline Yeast 2+ Arg & 10.52 & $38.88^{*}$ & 10.09 \\
\hline Yeast 2+B12 & $13.71^{*}$ & $48.08^{*}$ & 14.78 \\
\hline Yeast 4+Arg & 11.19 & $32.34^{*}$ & $26.47^{*}$ \\
\hline Yeast 4+B12 & $15.63^{*}$ & 42.76 & $35.83^{*}$ \\
\hline Yeast 6+ Arg & 11.18 & $38.02^{*}$ & 15.92 \\
\hline Yeast 6+B12 & $8.03^{*}$ & $41.25^{*}$ & $23.45^{*}$ \\
\hline LSD at 0.05 & 0.99 & 1.45 & 7.33 \\
\hline
\end{tabular}

* Significant at $5 \%$ confidence level. 
Response of wheat (Triticum aestivum L.) plants to Foliar Spraying of Some Bio stimulants

Table (7): Effect of yeast extract (g/l), arginine(ppm), B12(ppm) and their interactions on protein profile in the yielded seeds of Triticum aestivum L. (var. suds 1 ).

\begin{tabular}{|c|c|c|c|c|c|c|c|c|c|c|c|c|c|c|}
\hline \multirow{2}{*}{$\begin{array}{c}\text { Band } \\
\text { No. }\end{array}$} & \multirow{2}{*}{$\begin{array}{l}\text { M.W } \\
\text { KDa }\end{array}$} & \multicolumn{13}{|c|}{ Treatments } \\
\hline & & $\begin{array}{l}S \\
1 \\
\end{array}$ & $\begin{array}{l}S \\
2\end{array}$ & $\begin{array}{l}\mathrm{S} \\
3 \\
\end{array}$ & $\begin{array}{l}S \\
4 \\
\end{array}$ & $\begin{array}{l}\mathrm{S} \\
5\end{array}$ & $\begin{array}{l}S \\
6\end{array}$ & $\begin{array}{l}S \\
7 \\
\end{array}$ & $\begin{array}{l}S \\
8 \\
\end{array}$ & $\begin{array}{l}\text { S } \\
9 \\
\end{array}$ & $\begin{array}{c}\mathrm{S} \\
10\end{array}$ & $\begin{array}{c}\mathrm{S} \\
11 \\
\end{array}$ & $\begin{array}{c}S \\
12 \\
\end{array}$ & Polymorphism \\
\hline 1 & 147.471 & 0 & 0 & 0 & 0 & 0 & 1 & 0 & 0 & 0 & 1 & 0 & 0 & Polymorphic \\
\hline 2 & 139.984 & 0 & 0 & 0 & 0 & 0 & 1 & 0 & 0 & 0 & 1 & 0 & 0 & Polymorphic \\
\hline 3 & 132.877 & 0 & 0 & 0 & 0 & 0 & 1 & 0 & 0 & 0 & 1 & 0 & 0 & Polymorphic \\
\hline 4 & 125.745 & 0 & 0 & 0 & 0 & 0 & 1 & 0 & 0 & 0 & 1 & 0 & 0 & Polymorphic \\
\hline 5 & 97.503 & 0 & 1 & 1 & 1 & 1 & 1 & 1 & 1 & 1 & 1 & 1 & 1 & Polymorphic \\
\hline 6 & 87.854 & 0 & 1 & 1 & 1 & 1 & 1 & 1 & 1 & 1 & 1 & 1 & 1 & Polymorphic \\
\hline 7 & 65.863 & 0 & 0 & 0 & 0 & 0 & 0 & 0 & 1 & 1 & 1 & 1 & 1 & Polymorphic \\
\hline 8 & 60.262 & 0 & 1 & 1 & 1 & 1 & 1 & 1 & 1 & 1 & 1 & 1 & 1 & Polymorphic \\
\hline 9 & 56.853 & 0 & 1 & 1 & 1 & 1 & 1 & 1 & 1 & 1 & 1 & 1 & 1 & Polymorphic \\
\hline 10 & 47.887 & 0 & 1 & 1 & 1 & 1 & 1 & 1 & 1 & 1 & 1 & 1 & 1 & Polymorphic \\
\hline 11 & 33.354 & 1 & 1 & 1 & 1 & 1 & 1 & 1 & 1 & 1 & 1 & 1 & 1 & Monomorphic \\
\hline 12 & 31.18 & 1 & 1 & 1 & 1 & 1 & 1 & 1 & 1 & 1 & 1 & 1 & 1 & Monomorphic \\
\hline 13 & 28.88 & 1 & 1 & 1 & 1 & 1 & 1 & 1 & 1 & 1 & 1 & 1 & 1 & Monomorphic \\
\hline 14 & 25.705 & 0 & 1 & 1 & 1 & 1 & 1 & 1 & 1 & 1 & 1 & 1 & 1 & Polymorphic \\
\hline 15 & 20.869 & 1 & 1 & 1 & 1 & 1 & 1 & 1 & 1 & 1 & 1 & 1 & 1 & Monomorphic \\
\hline 16 & 17.258 & 1 & 1 & 1 & 1 & 1 & 1 & 1 & 1 & 1 & 1 & 1 & 1 & Monomorphic \\
\hline 17 & 13.341 & 1 & 1 & 1 & 1 & 1 & 1 & 1 & 1 & 1 & 1 & 1 & 1 & Monomorphic \\
\hline \multicolumn{2}{|c|}{$\begin{array}{c}18 \\
9.971\end{array}$} & 1 & 1 & 1 & 1 & 1 & 1 & 1 & 1 & 1 & 1 & 1 & 1 & Monomorphic \\
\hline Total & & 7 & 13 & 13 & 13 & 14 & 17 & 13 & 14 & 14 & 18 & 14 & 14 & \\
\hline
\end{tabular}

$\mathrm{S1}=$ control, $\mathrm{S2}=$ Yeast $(2 \mathrm{~g} / \mathrm{l}), \mathrm{S3}=$ Yeast $(4 \mathrm{~g} / \mathrm{l}), \mathrm{S} 4=$ Yeast $(6 \mathrm{~g} / \mathrm{l}), \mathrm{S5}=\mathrm{Arg}, \mathrm{S6}=\mathrm{B}_{12}, \mathrm{~S} 7=$ Yeast $(\mathbf{g g} / \mathrm{l})+\mathrm{Arg} ., \mathrm{S8}=$ Yeast $(2 \mathrm{~g} / \mathrm{l})+\mathrm{B}_{12}, \mathrm{~S} 9=$ Yeast $(4 \mathrm{~g} / \mathrm{l})+$ Arg.,, $\mathrm{S10}=$ Yeast $(4 \mathrm{~g} / \mathrm{l})+\mathrm{B}_{12}, \mathrm{S11}=$ Yeast $\left.(6 \mathrm{~g} / \mathrm{l})\right)+$ Arg.,, $\mathrm{S12}=$ Yeast $(6 \mathrm{~g} / \mathrm{l})+\mathrm{B}_{12}$

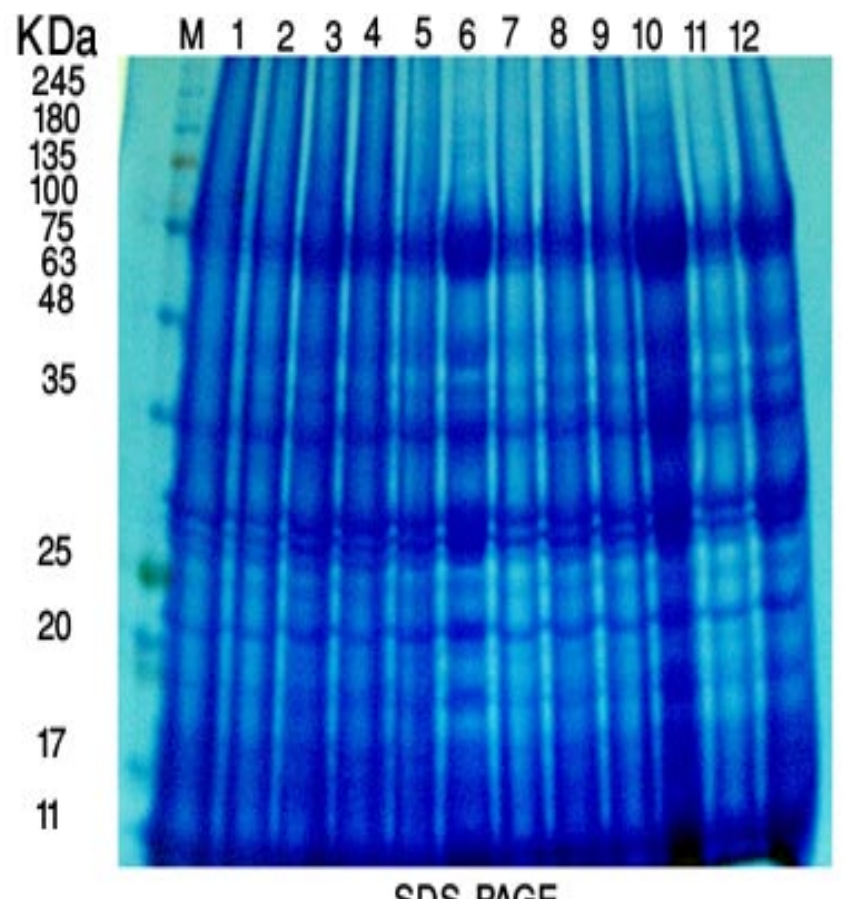

Figure (1): $1=$ control, $2=$ Yeast $(2 \mathrm{~g} /$ l), $3=$ Yeast $(4 \mathrm{~g} / \mathrm{l}), 4=$ Yeast $(6 \mathrm{~g} / \mathrm{l}), 5=\operatorname{Arg}, 6=\mathrm{B}_{12}, 7=$ Yeast $(2 \mathrm{~g} / \mathrm{l})+\mathrm{Arg}$., $8=$ Yeast $(2 \mathrm{~g} / \mathrm{l})+\mathrm{B}_{12}, 9=$ Yeast $(4 \mathrm{~g} /$ l) + Arg., $10=$ Yeast $(4 \mathrm{~g} / \mathrm{l})+$ $B_{12}, 11=$ Yeast $\left.(6 \mathrm{~g} / \mathrm{l})\right)+$ Arg., $12=$ Yeast $(6 \mathrm{~g} / \mathrm{l})+B_{12}$. 
tive growth and weight seeds /spike. Application of yeasts $2 \mathrm{~g} / 1$ increased the protein content of wheat by about $50 \%$. It significantly enhanced the overall growth of the treated plants. The mechanisms which could be involved include the bioavailability of macro and micronutrients, production of growth hormones.

\section{REFERENCES}

Abdel-Halim SM (1995): Effect of some vitamins as growth regulators on growth, yield and endogenous hormones of tomato plants during winter. Egypt J Appl Sci. 10 (12): 322-334

Abou El-yazied A.and Mady M.A. (2012): Effect of boron and yeast extract foliar application on growth, pod setting and both green and seed yield of broad bean (Vicia faba L.). J Amer Sci. 8 (4): 517-534

Abd El-Monem, A. A. (2007): Polyamines as modulators of wheat growth, metabolism and reproductive development under high temperature stress. Ph.D. Thesis, Ain Shamas Univ., Cairo, Egypt.

Afifi, W.M.; Ahmed, M.I.; Moussa, Z.A. and Abd El-Hamid, M.F. (1986): Effect of gamma irradiation and GA3 on amylase activity of pea seedlings. Ann. Agric. Sci., Moshtohor. 24(4):2047-2057. Amin

Agamy, R.; Hashem, M and Alamri, S. (2013): Effect of soil amendment with yeasts as bio-fertilizers on the growth and productivity of sugar beet. African J. of Agricultural Research Vol. 8(1), pp. 46-56.

Al-Said, M.A. and A.M. Kamal, (2008) : Effect of foliar spray with folic acid and some amino acids on flowering, yield and quality of sweet pepper. J. Agri. Sci., Mansoura Univ., 33(10): 7403-7412.

Awad, El-M.M., A.M. Abd El-Hameed and Z.A. El-Aimin, (2007) :Effect of Glycine, Lysine and nitrogen fertilizer rates on growth, yield and chemical composition of potato. J. Agric. Sci. Mansoura Univ., 32(10): 85418551.

Bahr, A.A. and Gomaa AM (2002): The integrated system of bio-and organic fertilizers for improving growth and yield of triticale. Egypt. J. Appl. Sci. 17(10):512-523.

Boraste, A.; Vamsi, K.K,; Jhadav, A.; Khairnar, Y.; Gupta, N.; Trivedi, S.; Patil, P.; Gupta, G.; Gupta, M.; Mujapara, A.K. and Joshi, B. (2009): Bio-fertilizers: A novel tool for agriculture. Int. J. Microbiol. Res. 1(2):23-31.

Bouchereau, A.; Aziz, A.; Larher, F. and Murting- Tanguy, J. (1999): Polyamines and development challenges recent development. Plant Sci., 140: 103-125.

Castelfranco, P.A.; Beale, S.I. (1983): Chlorophyll biosynthesis recent advances and areas of current interest. Ann. Rev. Plant Physiol. 34:241-278.

Cloete K, Valentine A, Stander M, Blomerus L, Botha A (2009): Evidence of symbiosis between the soil yeast
Cryptococcus laurentii and a sclerophyllous medicinal shrub, Agathosma betulina (Berg.) Pillans. Microb. Ecol. 57:624632.

Daniel, H.D. and George, C.M. (1972): Peach seed dormancy in relation to endogenous inhibitors and applied growth substances. J. Amer. Soc. Hort. Sci. 97:651654.

Ekmekçi, B. A. and Karaman, M. (2012): Exogenous ascorbic acid increases resistance to salt of Silybum marianum (L.). African Journal of Biotechnology Vol. 11(42), pp. 9932-9940.

El-Bassiouny, H. M. S.; Mostafa, H. A.; El-Khawas, S. A.; Hassanein, R. A.; Khalil, S. I.; Abd El-Monem, A. A. (2008): Physiological responses of wheat plant to foliar treatments with arginine or putrescine. Austr. J. of Basic and Applied Sci., 2(4): 1390-1403.

El-Shabasi, M.S., S.M. Mohamed and S.A. Mahfouz, (2005) :Effect of foliar spray with some amino acids on growth, yield and chemical composition of garlic plants. The 6th Arabian Conf. for Hort., Ismailia, Egypt.

El-Tarabily KA, Sivasithamparam K (2006): Potential of yeasts as biocontrol agents of soil-borne fungal plant pathogens and as plant growth promoters. Mycoscience 47:25-35.

El-Tohamy WA, El-Abagy HM, El-Greadly HM (2008): Studies on the effect of putrescine, yeast and vitamin $\mathrm{C}$ on growth, yield and physiological responses of eggplant (Solanum melongena L.) under sandy soil conditions. Aust J Basic Appl Sci. 2 (2): 296-300.

Ewais, A.E.; Farghal, I.I. and Tobal, Y.F. (2003): Effect of Kinetin, riboflavin and zinc on gowth, flowering and biochemical constituents of Zinnia elegans and Celosia argentea plants. Journal of the Faculty of Education, Ain shams university, 28: 189-205.

FAO., (2008) Statistical databases. Food Composition Table for Use in the Near East. Food and Agriculture Organization. for Phillyrea angustifolia. Hort Sci. 36, 449-500.

Fawzy Z.F.; El-Shal, Z.S.; Yunsheng, L.; Zhu, O. and Sawan O.M. (2012) Response of garlic (Allium Sativum L.) plants to foliar spraying of some bio- stimulants under sandy soil condition. Appl Sci Res. 8 (2): 770-776.

Fathy, E.S.L, Farid, S. (1996): The possibility of using vitamin Bs and yeast to delay senescence and improve growth and yield of common beans (Phaseolus vulgaris L.). J Agric Sci Mansoura Univ. 21 (4): 1415-1423.

Galston, A.W. and Kaur-Sahney (1990): Polyamines in plant physiology. Plant Physiol. 94,406.

Hesham A-Land Mohamed H (2011): Molecular genetic identification of yeast strains isolated from Egyptian soils for solubilization of inorganic phosphates and growth promotion of corn plants. J. Microbiol. Biotechnol. 21:55-61. 
Hayat, A.E. (2007). Physiological studies on Hibiscus sabdariffa L. production in new reclamated soils. M.Sc. thesis, Faculty of Agriculture, Zagazig University.

Hussain, T., Anjum, A.D., Tahir, J. (2002): Technology of beneficial microorganisms. Nat. Farm. Environ. 3:114.

Kamar, M.E. and A. Omar, )1987( : Effect of nitrogen levels and spraying wihaminal-forte (amino acids salvation) on yield of cucumber and potatoes. J. Agric. Sci. Mansoura Univ., 12(4): 900-907.

Khalil, S.E.; Ismael, E.G. (2010). Growth, Yield and Seed Quality of Lupinus termis as Affected by Different Soil Moisture Levels and Different Ways of Yeast Application. J. Americ. Sci. 6(8):141-153.

Kowalczyk K and Zielony T (2008): Effect of amino plant and asahi on yield and quality of lettuce grown on rockwool. Proc. Conf. of Bio stimulators in Modern Agriculture, 7-8 Febuary, Warsaw, Poland

Lichtenthaler, H.K. (1981): Photosynthesis IV. Philadelphia. Balaban Internat Science Service. p. 273-285.

Lowry, O.H.; Rosebrough, N.J.; Furr, A.I. and Randall, R.J. (1951): Protein measurement with folin phenol reagents. J. Biol. Chem, 193: 265-275.

Mahdi SS, Hassan GI, Samoon SA, Rather HA, Showkat AD, Zehra B (2010): Bio-fertilizers in organic agriculture. J. Phytol. 2(10):42-54.

Mekki BB, Ahmed, AG (2005): Growth, Yield and Seed Quality of Soybean (Glycine max L.) As Affected by Organic, Bio-fertilizer and Yeast Application. Res. J. Agric. Biol. Sci.1(4):320-324.

Nakayan P, Shen FT, Hung MH, Young CC (2009): Effectiveness of Pichia sp. CC1 in decreasing chemical fertilization requirements of garden lettuce in pot experiments. As. J. Food. Ag-Ind. Special. S66S68.

Nassar A. H.; El - Tarabily K. A. and Sivasithamparam K. (2003): Growth promotion of bean (Phaseolus vulgaris L.) by a polyamine -producing isolate of Streptomyces griseoluteus. Plant Growth Regul. Kluwer Academic
Publishers, Dordrecht, Netherlands 40: (2) $97-106$.

Nassar A, El-Tarabily K, Sivasithamparam K (2005): Promotion of plant growth by an auxin-producing isolate of the yeast Williopsis saturnus endophytic in maize (Zea mays L.) roots. Biol. Fert. Soils. 42:97-108.

Omran, Y.A. (2000): Studies on histophysiological effect of hydrogen cyanamide (Dormex) and yeast application on bud fertility, vegetative growth and yield of "Roumi Red"' grape cultivar. Ph. D. Thesis, Fac. of Agric. Assiut Univ. Egypt.

Rafique, N.; Raza, S. H.; Qasim, M. and abd Iqbal, N. (2011): Pre-sowing application of ascorbhc acid and salicylic acid to seed of pumpkin and seedling to salt. Pak. J. Bot., 43(6): 2677-2682.

Reda F.; Baroty, G.S.A.; Talaat, I.M.; Abdel-Rahim, I.A. and Ayad, H.S. (2007): Effect of some growth regulators and vitamins on essential oil, phenolic contents and activity of oxidoreductase enzymes of Thymus vulgaris L. World Journal of Agricultural Sciences 3 (5): 630638.

Snedecor, G.M. and Cochran, W.G. (1982): Statistical methods 7 edition, lowa state Univ., Press, Ames, thlowa U.S.A., pp: 325-330.

Stino, R.G., Mohsen, A.T., Maksouds, M.A., Abd El- Migeed, M.M.M., Gomaa, A.M., Ibrahim, A.Y. (2009): Bioorganic fertilization and its Impact on Apricot young trees in newly reclaimed soil. American- Eurasion. J. Agric. Environ. Sci. 6(1):62-69.

Umbriet, W.W.; R.H. Burris, J.F.; stauffer, P.P.;Cohen, W.J.; Johsen, L. G.A.; page, V.R.; and W.C. Schneicter, 1969. Manometric techniques, manual describing methods applicable to the studs of tissue metabolism. Burgess publishing Co., U.S.A., pp: 239.

Vernon, L.P. and Selly, G.R. (1966): The chlorophylls. Acad. Press, New York, London.

Wali Asal, M.A.(2010): The combined Effect of mineral organic and biofertilizers on the productivity and quality of some wheat cultivars. Ph.D. Thesis, Fac. Agric. Alex. Univ., Egypt 


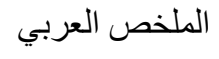

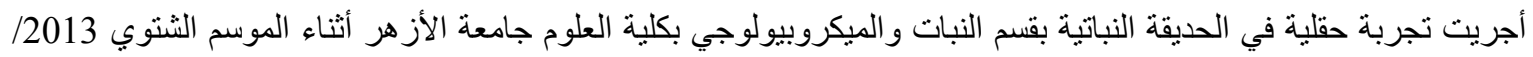

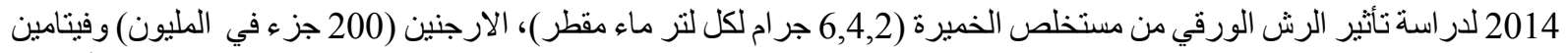

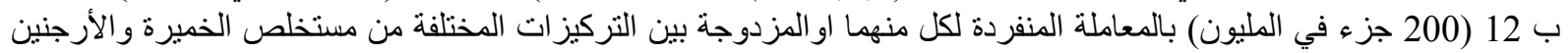

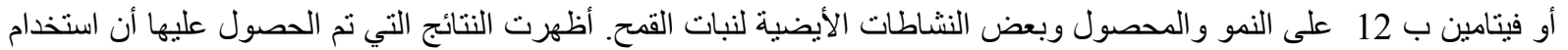

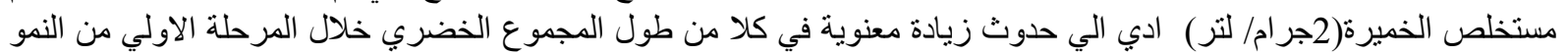

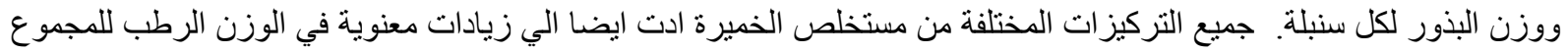

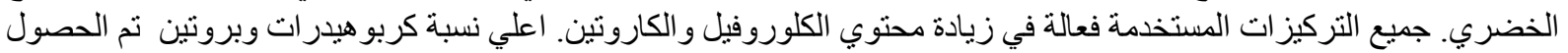

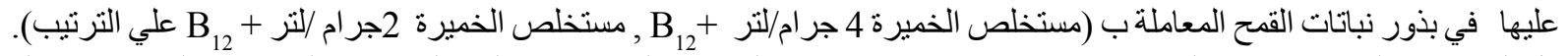

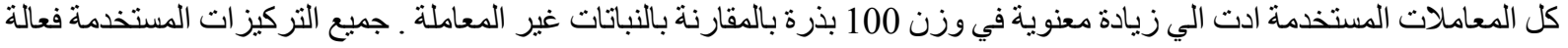

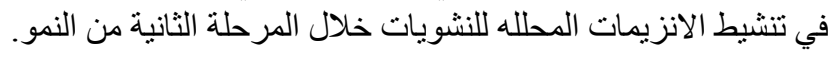

